\title{
Effects of Ethanol Extract of Pterocarpus Erinaceus Leaves and Potassium Bromate Administration on Some Biochemical and Haematological Indices in Albino Rats
}

Joseph Eniola Oladije, Daniel Ojochenemi Apeh*, Favour Moses Idih, Isaac Eleojo Shaibu, Hadiza Tahir Shuaibu, Dorcas Ojoma Ameh

Department of Biochemistry, Kogi State University Anyigba, Kogi State, Nigeria

\begin{tabular}{|c|c|}
\hline $\begin{array}{c}\text { Article History } \\
\text { Received: } 03.09 .2020 \\
\text { Accepted: } 25.09 .2020 \\
\text { Published: } 14.10 .2020 \\
\\
\text { Journal homepage: } \\
\text { https://www.easpublisher.com/easjpp }\end{array}$ & $\begin{array}{l}\text { Abstract: This study evaluated the effect of the administrations of ethanol extract of } \\
\text { Pterocarpus erinaceus leaves and potassium bromate respectively and in combination on } \\
\text { serum electrolytes, total protein, lipid profile and haematological parameters in albino rats. } \\
\text { The experimental animals were divided into four groups: Group A (control) was } \\
\text { administered water, group B were administered } 200 \mathrm{mg} / \mathrm{kg} \text { potassium bromate, group C } \\
\text { were administered } 200 \mathrm{mg} / \mathrm{kg} \mathrm{P} \text {. erinaceus extract and group D were administered a } \\
\text { combined dose of } 200 \mathrm{mg} / \mathrm{kg} \text { potassium bromate and } 200 \mathrm{mg} / \mathrm{kg} \text { of } P \text {. erinaceus extract, all } \\
\text { the administrations were done orally and continued daily for } 21 \text { days. It was observed in } \\
\text { this study that potassium bromate decreased bicarbonate ion in the serum while the } \\
\text { administration of } P \text {. erinaceus extract alone and in combination with potassium bromate } \\
\text { increased bicarbonate ion in the serum. Rats administered with potassium bromate } \\
\text { exhibited slight symptoms of toxicity while the Pterocarpus erinaceus leave extract } \\
\text { showed a strong preventive effect against some biomarkers of cardiovascular damage. } \\
\text { Groups administered the combined dose of potassium bromate and the extract showed a } \\
\text { uniform percentage increase in white blood cell, lymphocytes, hemoglobin, hematocrit, } \\
\text { mean corpuscular volume accompanied by a decrease in red blood cells and platelet. The } \\
\text { research reaffirmed the negative food safety impact associated with the consumption of } \\
\text { potassium bromate, the ameliorative effect of the ethanol extract of } P \text {. erinaceus and its } \\
\text { potential in preventing cardiovascular diseases. } \\
\text { Keywords: Pterocarpus erinaceus, potassium bromate, serum electrolytes, total protein, } \\
\text { lipid profile, haematological parameters. }\end{array}$ \\
\hline & \\
\hline
\end{tabular}

\section{INTRODUCTION}

Some substances called food additives are incorporated into foods during processing to enhance their quality [1]. Generally, food additives can be classified into those intentionally added and those that get into food in small amounts due to food storage and handlings practices [2]. Various additives are approved by Codex Alimentarus [35] Commission and their maximum limit has also been set based on their potential toxic effects [2]. A white crystalline salt called potassium bromate $\left(\mathrm{KBrO}_{3}\right)$ was listed as flour treatment agent by $\mathrm{FAO} / \mathrm{WHO}$ [36], and used for several years in the baking and confectionery industry to enhance the flavor of products $[3,1]$. The use of potassium bromate was challenged with its official ban having been classified as a Category $2 \mathrm{~B}$ carcinogen by IARC [4]. Toxicological studies have revealed that potassium bromate has potential to cause disruption of the plasma membrane of cells as an oxidizing agent and cause cells to empty their internal contents to the extracellular environment and it is also toxic to organs $[5,6]$. Potassium bromate was shown to initiate kidney toxicity in experimental animals and man [7], it was also reported to ignite DNA damage membrane and lipids peroxidation [8]. In addition, there are claims that potassium bromate could induce cancer $[9,10]$. An increase in the occurrence of both malignant and benign tumors was observed after administration of potassium bromate, in the membrane that lines the abdominal cavity of laboratory animals [11]. Also, administration of potassium bromate led to a major increase in cancers of the thyroid, kidneys, and other organs of the animals [12].

Pterocarpus erinaceus is commonly referred to as Bloodwood/ Barwood in English and "Maijinni" in Hausa language. It has been attributed the status of a wonder herb, since it can cure various ailments when used in traditional medicine. The ailments include fever, intestinal worms, diarrhea, gonorrhea, dysentery, and externally to treat ulcers, eye complaints, and sores. 
According to Anne [13], the phytochemicals reported to be possessed by the plant includes; saponins, tannins, triterpenoids, flavonoids and steroids. The ethanolic stem bark extract has exhibited potentials in resolving inflammatory pathologies like dermatitis, gastric ulcer, rheumatism in addition to antimicrobial and antimalarial properties [14]. The bark or roots has been used to treat toothache, bronchial infections, anaemia, menstruation complaints, post-partum haemorrhage, leprosy, ringworms, wounds, antiemetic, tumors, purgative and tonic. Leaf decoctions are applied to treat syphilis [15]. Anne [13] reported that the aqueous extract of Pterocarpus erinaceus stem bark possessed analgesic, antioxidant, and anti-inflammatory properties. The plant has been found to be inhibitory against malaria parasite [16], possess anti-gonadotropic properties [17], as well as having anti-helmintic properties [18]. Etuk et al. [19] had reported in-vivo and in-vitro anti-mycotic activity of the plant. Plants generally have formed the basis of traditional medicine system which has a rapidly growing economic importance [20]. The fact remains that a large population of Africans are unable to afford modern medicine as a result; traditional medicine is usually their recourse [21].

This research is designed to ascertain the effect of administration of the ethanol extract of Pterocarpus erinaceus on the electrolytes, liver total protein and serum lipid profile of albino rats treated with potassium bromate. This is to further verify the ameliorative effect of the plant extract on potassium bromate toxicity and potentially, its effect on mitigating toxicity associated with toxicants of the same mode of induction as potassium bromate.

\section{MATerials AND Method}

Albino rats weighing between $120-180 \mathrm{~g}$ were obtained from the Animal House, Department of Biochemistry, Kogi State University, and Anyigba, Nigeria. The rats were acclimatized for 2 weeks prior to the experiment and exposed to 12 hours light and darkness while allowed access to food and water at libitum. The experimental animals were handled according to the guidelines set by the Research Ethical Committee of Kogi State University, Anyigba, Nigeria.

All the reagents and chemicals used for the study were of analytical grade and all the equipment were of laboratory standard.

\section{Preparation of Extract}

The leaves of Pterocarpus erinaceus were harvested from Kogi State University Campus and identified in the Department of Biological Sciences of the same Institution.

The leaves were air-dried for 2 weeks and pulverized. The pulverized sample was soaked in ethanol, constituted as $1 \mathrm{~g}$ of dried extract powder in 3 $\mathrm{ml}$ of solvent, left for about 72 hours for maximum extraction of sample constituent. The extract was filtered using vacuum filtration method, the filtrate was concentrated using a rotary evaporator.

\section{Experimental Animal Grouping}

Table-1.0: Animal group treatments

\begin{tabular}{|l|l|l|l|}
\hline Group & $\begin{array}{c}\text { Number of } \\
\text { animal }\end{array}$ & $\begin{array}{c}\text { Pterocarpus erinaceus } \\
\text { Extract }(\mathbf{2 0 0} \mathbf{m g} / \mathbf{k g})\end{array}$ & Potassium bromate $(\mathbf{2 0 0 m g} / \mathbf{k g})$ \\
\hline A & 5 & & \\
\hline B & 5 & & $\sqrt{ }$ \\
\hline C & 5 & $\sqrt{ }$ & $\sqrt{ }$ \\
\hline D & 5 & $\sqrt{ }$ & \multicolumn{2}{|l}{} \\
\hline
\end{tabular}

\section{Collection of Blood/ Serum}

The blood sample was collected in plain sample container and immediately placed in the centrifuge; the centrifuge was powered and timed at $3000 \mathrm{rpm}$. After the time elapsed, the serum which appeared at the top of the bottle was collected with a syringe and stored in the freezer for analysis. Whole blood was collected into EDTA bottles, for the determination of hematological parameters.

\section{Determination of Total Protein}

This was done using a method by Gornall et al.

\section{Total cholesterol}

This was determined using a standard method by Flegg et al. [23].

\section{HDL Cholesterol}

This was carried out usin a method as detailed by Friedewald et al. [24].

\section{Triglyceride}

This was done following a method by Tietz et al. [25] and McGowan et al. [26], 


\section{Determination of sodium ion, potassium ion and} chloride ion in serum

Colorimetric method was used for the determination of sodium and chloride while turbidimetric method was used for the determination of potassium in the serum.

\section{RESULTS AND DISCUSSION}

Administration of potassium bromate (PB), Pterocarpus erinaceus (PE) and their combined (CO) dose in albino rats showed several effects on the test animals studied. Generally resulting from all treatments, there was a decrease in total protein (Figure 1a) compared to the control, this decrease was higher with the co-administration of PB and PE (group D). The significant reduction in total protein at 21 days is indicative of a possible disruption of the protein synthesis machinery; this suggests that hepatotoxicity may have set in. This trend of increase and decrease in total protein observed during the course of treatment has been reported by Omer et al. [27]. An initial increase in total cholesterol (Figure 1b) levels above the control was observed in the first day of the coadministration, and first 5 days for potassium bromate and Pterocarpus erinaceus treatments respectively. The total cholesterol level decreased in the group administered Pterocarpus erinaceus and co- administered PB and PE respectively on day 21 day. There was no significant $(p>0.05)$ increase in HDL levels when compared to the control group (Figure 1c). However, for the PE treated group, there was a significant $(p>0.05)$ increase in HDL concentration in the first 15 days. The PE and PB treatments resulted in an increase in TAG level in the first 15 days (Figure 1e). The increase resulting from PE was significantly higher $(\mathrm{p}<0.05)$ than the control. Co-administration of $\mathrm{PE}$ and $\mathrm{PB}$ resulted in lower TAG concentration. It was observed that the concentration of LDL was high but decreased remarkable on day 21 probably due to the increases of in HDL concentration [28]. Many studies have reported that increased level of LDL is associated with higher risk of atherosclerosis while elevated level of HDL is linked to reduced occurrences of cardiovascular disorders $[29,30]$.

The result of this study shows a significant increase in HDL concentration, a progressive decrease in LDL concentration and a corresponding decrease in total cholesterol (TC) and triglyceride (TAG) concentration. The study showed that the ethanol extract of Pterocarpus erinaceus has the potential of increasing the HDL/LDL ratio and as such will have a strong effect in preventing cardiovascular diseases.

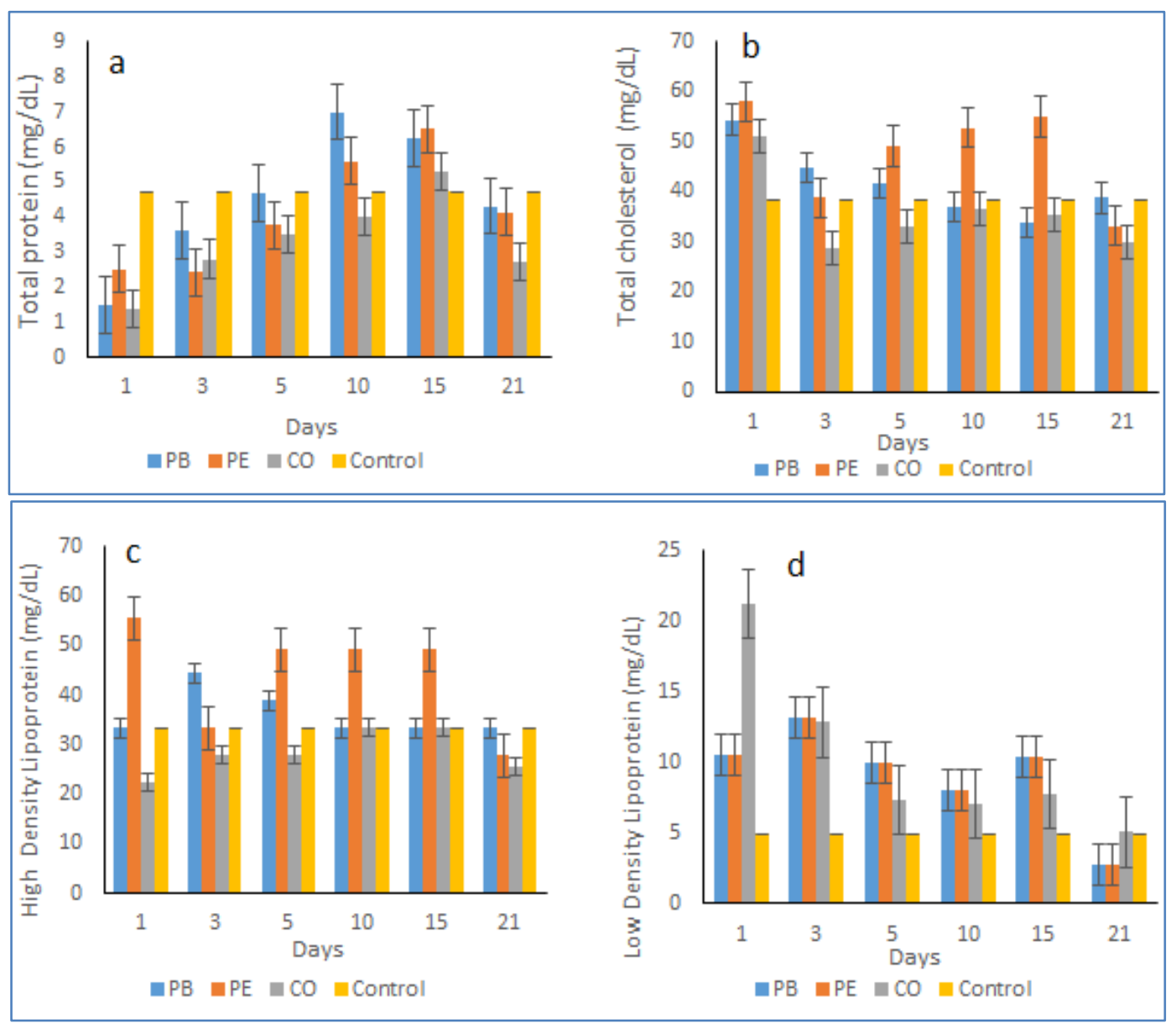




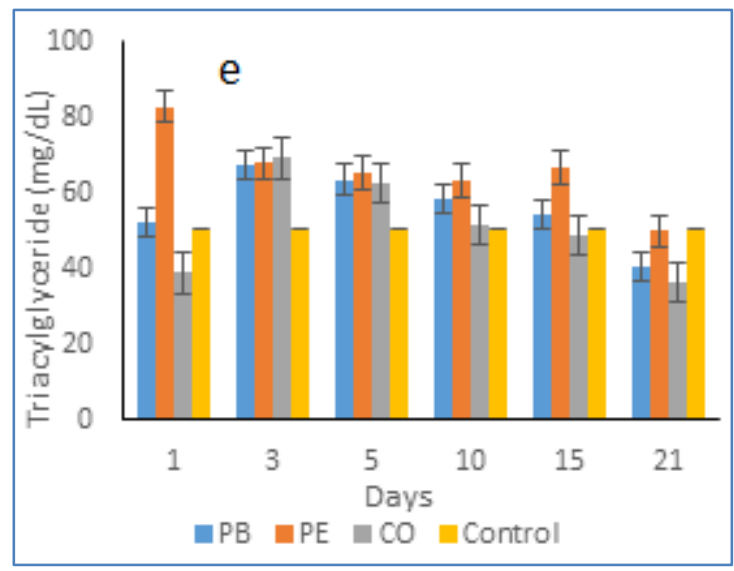

Fig-1: Effects of Potassium bromate, Pterocarpus erinaceus and their combination on some blood parameters in albino rats Note: $\mathrm{PB}=$ Potassium bromate, $\mathrm{PE}=$ Pterocarpus erinaceus, $\mathrm{CO}=$ Potassium bromate + Pterocarpus erinaceus

In the first 15 days of treatment, the three treatments significantly dropped the level of sodium in the blood (Figure 2a), with Pterocarpus erinaceus treatment having the greatest impact followed by potassium bromate. The level of bicarbonate (Figure 2b) was significantly higher than the control after 21 days for the Pterocarpus erinaceus and co-administered treatments, but below control for the potassium bromate treatment. Potassium level was higher than control with the 3 treatment up to 15 days but by 21 days (Figure $2 \mathrm{c})$, they had all reduced below control. There was no significant $(p>0.05)$ difference in the level of chloride ion (Figure $2 \mathrm{~d}$ ) in the blood during the treatment time. Reduction of sodium levels increases kidney excretion of water. Kurokawa et al. [31] had reported a lethal dose of potassium bromate in rats between $280-495$ $\mathrm{mg} / \mathrm{kg}$ bw.

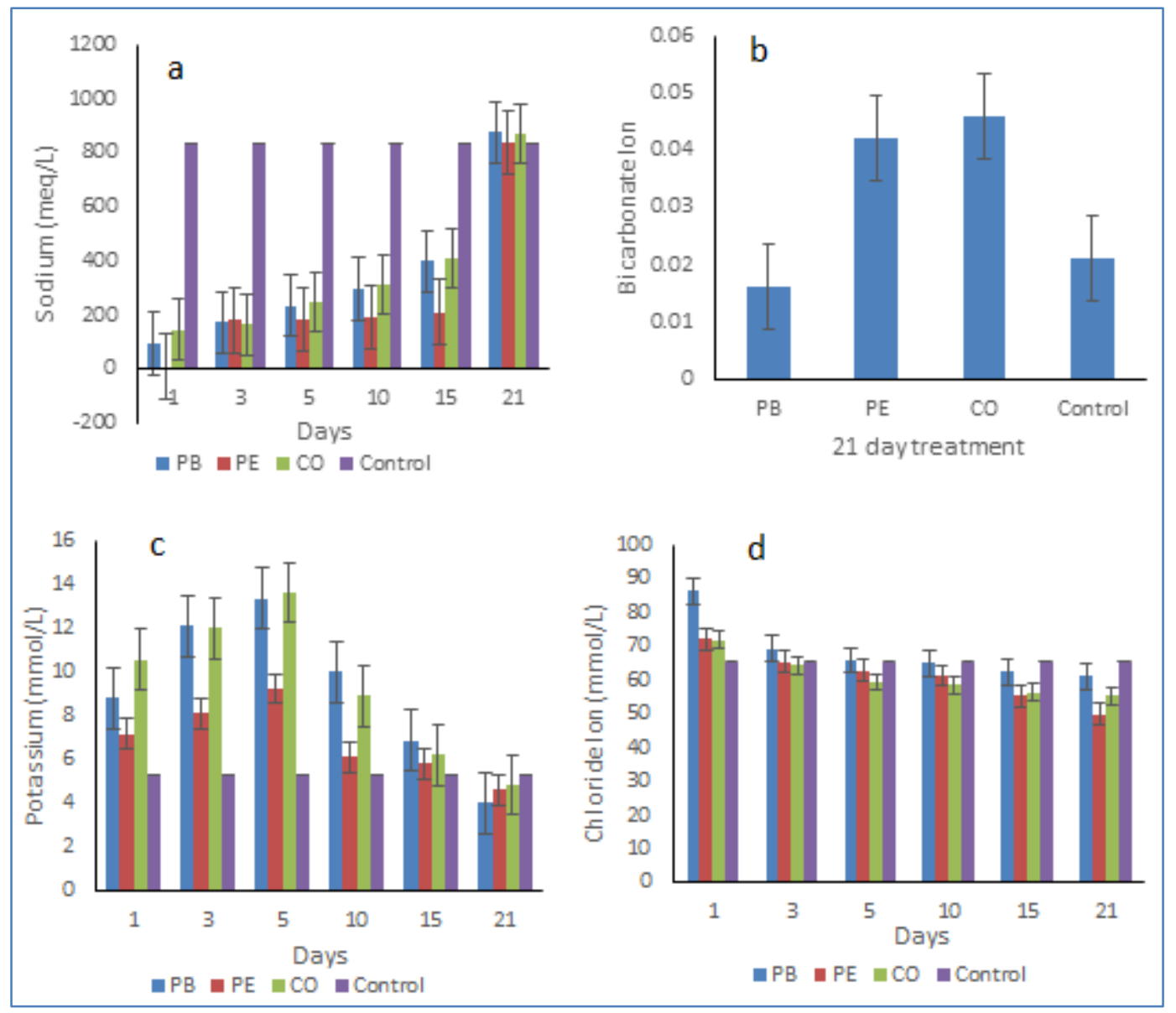

Fig-2: Effects of Potassium bromate, Pterocarpus erinaceus and their combination on serum electrolytes in albino rats 
Table-2.0: Effects of Potassium bromate, Pterocarpus erinaceus and their combination on Haematological parameters

\begin{tabular}{|l|l|l|l|l|}
\hline S/N & $\begin{array}{l}\text { Haematological } \\
\text { parameter }\end{array}$ & $\begin{array}{l}\text { Potassium } \\
\text { bromate }(\%)\end{array}$ & $\begin{array}{l}\text { Pterocarpus } \\
\text { erinaceus }(\%)\end{array}$ & $\begin{array}{l}\text { Potassium bromate }+ \\
\text { Pterocarpus erinaceus }(\%)\end{array}$ \\
\hline 1 & WBC & $25 \pm 2.3^{\mathrm{a}}$ & $23 \pm 1.1^{\mathrm{a}}$ & $49 \pm 2.5^{\mathrm{b}}$ \\
\hline 2 & LYM & $17 \pm 1.2^{\mathrm{b}}$ & $9 \pm 2.2^{\mathrm{a}}$ & $16 \pm 2.0^{\mathrm{b}}$ \\
\hline 3 & HGB & $16 \pm 1.0^{\mathrm{b}}$ & $14 \pm 0.8^{\mathrm{b}}$ & $8 \pm 1.0^{\mathrm{a}}$ \\
\hline 4 & HCT & $20 \pm 2.8^{\mathrm{b}}$ & $8 \pm 2.5^{\mathrm{a}}$ & $19 \pm 2.1^{\mathrm{b}}$ \\
\hline 5 & MCV & $20 \pm 0.7^{\mathrm{c}}$ & $14 \pm 0.0^{\mathrm{a}}$ & $16 \pm 1.9^{\mathrm{b}}$ \\
\hline 6 & RBC & $-4 \pm 0.2^{\mathrm{c}}$ & $-2 \pm 0.1^{\mathrm{a}}$ & $-3 \pm 0.0^{\mathrm{b}}$ \\
\hline 7 & PLT & $-22 \pm 2.1^{\mathrm{b}}$ & $-21 \pm 0.5^{\mathrm{b}}$ & $-11 \pm 0.0^{\mathrm{a}}$ \\
\hline
\end{tabular}

Note: Values are presented as Mean \pm SEM of duplicate determinations. Value with different superscript alphabets across a row are significantly $(\mathrm{p}<0.05)$ different. Values represent \% increase in haematological parameters as a result of treatments when compared to the control. (-) sign represents \% decrease in haematological parameters as a result of treatments when compared to the control. white blood cell (WBC), lymphocytes (LYM), haemoglobin (HGB), hematocrit (HCT), mean corpuscular volume (MCV), red blood cells (RBC) and platelet (PLT).

The white blood cell increase triggered by the co-administration was significantly $(p<0.05)$ higher than that caused by the individual treatments based on comparison with the control (Table 2). The platelet count showed statistically significant $(\mathrm{p}<0.05)$ decrease in post administration rats when compared with the control. The lymphocyte and hematocrit values recorded for Pterocarpus erinaceus extracts were significantly lower $(\mathrm{p}<0.05)$ when compared to other treatments, however the difference in the levels of increase triggered for both lymphocyte and haematocrit by $\mathrm{PB}$ treatment and $\mathrm{CO}$ treatments were not significant ( $>0.05)$ (Table 2). Both red blood cell and platelet levels decreased irrespective of treatments. In both cases, potassium bromate administration triggered the most decrease. In contrast, mean corpuscular volume levels had its highest increase with the potassium bromate treatment, the lowest being associated with Pterocarpus erinaceus treatment. The reduction in platelet count could be due to the DNA strand breakage in these cells induced by the oxidative stress associated with potassium bromate $[10,9]$. It has been established that the haematopoietic system is very sensitive to toxic compounds and serves as an important index of the physiological and pathological status in both animals and humans [32, 33]. According to Nadro and Modibbo [34], the administration of Pterocarpus erinaceus stem bark aqueous extract orally at over $5000 \mathrm{mg} / \mathrm{kg}$ did not induce any form of toxicity in rat, there was no mortality, weakness or any visible sign of toxicity and it is therefore safe for use in treatment of diseases [14]. The intraperitoneal $\mathrm{LD}_{50}$ of the ethanolic stem bark extract of $P$. erinaceus was found to be $447.21 \mathrm{mg} / \mathrm{kg}$, while the oral $\mathrm{LD}_{50}$ was $>5000 \mathrm{mg} / \mathrm{kg}$, hence it may be practically non-toxic through the (oral) route and may contain some biologically active principle(s) which may be responsible for the haemostasis [14]. This research therefore validates the use of $P$. erinaceus as herb for management of several ailments especially cardiovascular diseases.

\section{CONCLUSION}

This research reaffirms the negative food safety impact associated with the consumption of potassium bromate, and the ameliorative effect of the ethanol extract of $P$. erinaceus and its potential in preventing cardiovascular diseases.

Conflict of Interest: The authors declare that there is no conflict of interest

\section{REFERENCES}

1. Abdulmumeen, H. A., Risikat, A. N., \& Sururah, A. R. (2012). Food: Its preservatives, additives and applications. International Journal of Chemical and Biochemical Sciences, 1(2012), 36-47.

2. Cavanaugh, T. A. (2002). Bioethics, 4/17 Medical Ethics. Blackwell Publishing Limited, England

3. Achukwu, P. U., Ufelle, S. A., Ukaejiofo, E. O., \& Nwachukwu, D. N. (2009). The effect of potassium bromate on some haematological parameters of wistar rats. Nigeria Journal of Physiology and Science, 24(1): 59 - 61.

4. IARC. (1999). Potassium Bromate - Summary of Data Reported and Evaluation, 73: 481 Available from: http://www.inchem.org/documents/iarc/vol73 /73-17.html

5. Akanji, M. A., Nafiu M. O., \& Yakubu, M. T. (2008). Enzyme activities and histopathology of selected Tissues in rats treated with potassium bromate. African Journal of Biomedical Research, 11: $87-95$.

6. Olajide, J. E., Ojogbane, B. E., \& Ayeni, C. (2015). Protective activity of acetylsalicylic acid on biochemical markers of hepatic and renal functions in rats administered with potassiumbromate. Biolife, 3(1): 317 - 326.

7. Uchida, H. A., Sugiyama, H., Kanehisa, S., Harada, K., Fujiwara, K., Ono, T., \& Makino, H. (2006). An elderly patient with severe acute renal failure due to sodium bromate intoxication. Internal Medicine, 45(3), 151-154. 
8. Adekoya, A. O., Adekoya, B. J. Desalu, O. O., \& Aderibigbe, A. (2011). Patterns of lipid profile in adult nephritic syndrome patients in Nigeria. International Journal of Biology and Medical Research, 2(4), $954-960$.

9. Sai, K., Umemura, T., Takagi, A., Hasegawa, R. and Kurokawa, Y. (1992). The protective role of glutathione, cysteine and vitamin $\mathrm{C}$ against oxidative DNA damage induced in rat kidney by potassium bromate. Jpn J. Cancer Res., 83, 45-51.

10. Chipman, J. K., Davies, J.K., Parson, J.L., Nair, J., O'Neill, G., \& Fawell, J.K. (1998). DNA oxidation by potassium bromate; a direct mechanism or linked to lipid peroxidation. Toxicol. 126, 93-102

11. Kurokawa, Y., Aoki, S., Matsushima, Y., Takamura, N., Imazawa, T., \& Hayashi, Y. (1986). Dose-response studies on the carcinogenicity of potassium bromate in F344 rats after long-term oral administration. Journal of the National Cancer Institute, 77(4), 977-982.

12. DeAngelo, A. B., George, M. H., Kilburn, S. R., Moore, T. M., \& Wolf, D. C. (1998). Carcinogenicity of potassium bromate administered in the drinking water to male $\mathrm{B} 6 \mathrm{C} 3 \mathrm{~F} 1$ mice and F344/N rats. Toxicologic pathology, 26(5), 587594.

13. Ouedraogo, N., Tibiri, A., Sawadogo, R. W., Lompo, M., Hay, A. E., Koudou, J., ... \& Guissou, I. P. (2011). Antioxidant anti-inflammatory and analgesic activities of aqueous extract From stem bark of Pterocarpus erinaceus Poir.(Fabaceae). Journal of Medicinal Plants Research, 5(10), 2047-2053.

14. Salawu, O. A., Aliyu, M., Tijani, A. Y. (2008). Haematological studies on the ethanolic stem bark extract of Pterocarpus erinaceus (fabaceae). African Journal of Biotechnology 7(9): 1212-15. (ISSN:1684-5315

15. Duvall, O.S. (2016). Pterocarpus erinaceus poir. Retrieved from Prota. http://www.prota 4u.org/search .asp.>accessed 15th, March 2019.

16. Karou, D., Dicko, M. H., Sanon, S., Simpore, J., \& Traore, A. S. (2003). Antimalarial activity of Sida acuta Burm. f.(Malvaceae) and Pterocarpus erinaceus Poir.(Fabaceae). Journal of ethnopharmacology, 89(2-3), 291-294.

17. Benie, T., Duval, J., \& Thieulant, M. L. (2003). Effects of some traditional plant extracts on rat oestrous cycle compared with clomid. Phytotherapy research, 17(7), 748-755.

18. Koné, W. M., Atindehou, K. K., Dossahoua, T., \& Betschart, B. (2005). Anthelmintic activity of medicinal plants used in northern Côte d'Ivoire against intestinal helminthiasis. Pharmaceutical biology, 43(1), 72-78.

19. Etuk, E. U., Suberu, H. A., Ameh, I. G., \& Abubakar, K. (2008). Anti-mycotic effect of the aqueous leaf extract of Pterocarpus erinaceus in rats. $J P T, 3,318-323$.
20. Agra, M. D. F., Freitas, P. F. D., \& Barbosa-Filho, J. M. (2007). Synopsis of the plants known as medicinal and poisonous in Northeast of Brazil. Revista Brasileira de Farmacognosia, 17(1), 114-140.

21. Macía, M. J., García, E., \& Vidaurre, P. J. (2005). An ethnobotanical survey of medicinal plants commercialized in the markets of $\mathrm{La} \mathrm{Paz}$ and $\mathrm{El}$ Alto, Bolivia. Journal of ethnopharmacology, 97(2), 337-350.

22. Gornall, A. G., Bardawill, C. J., \& David, M. M. (1949). Determination of serum proteins by means of the biuret reaction. Journal of biological chemistry, 177(2), 751-766.

23. Flegg, H.M. (1973). An investigation of the determination of serum cholesterol by an enzymatic method. Ann Clin Biochem, 10, 79-84.

24. Friedewald, W.T., Levy, R.I., Fredrickson, D.S. (1990). Estimation of the concentration of lowdensity lipoprotein cholesterol in plasma, without use of the preparative ultracentrifuge. Clin Chem, 1972; 18:499-502.

25. Tietz, N. W., Borden, T., \& Stepleton, J. D. (1959). An improved method for the determination of lipase in serum. American journal of clinical pathology, 31, 148-154.

26. McGowan, M. W., Artiss, J. D., Strandbergh, D. R., \& Zak, B. (1983). A peroxidase-coupled method for the colorimetric determination of serum triglycerides. Clinical chemistry, 29(3), 538-542.

27. Omer, R., Abuelgasim, A. I., \& Elmahdi, B. (2008). Effect of Potassium Bromate on Liver and Blood Constituents of Wistar Albino Rats. American Journal of Food Technology, 3: 310-314.

28. Superko, H.R., Nejedly, M., Garrett, B. (2002). Small LDL and its clinical importance as a new CAD risk factor: a female case study. Prog Cardiovasc Nurs, 17,167-73.

29. Grover-Paez, F., Zavalzaomez, A.B. (2009). Endothelial dysfunction and cardiovascular risk factors. Diab. Res. and Clin. Prac, 84, 1-10.

30. Olukanni, O.D., Akande, O.T., Alagbe, Y.O., Adeyemi, O.S., Olukanni, A.T., Daramola, G.G., (2013). Lemon juice elevated level of reduced glutathione and improved lipid profile in Wistar rats. American-Eurasian J. of Agricul. \& Environ. Sci. 13, 1246-1251.

31. Kurokawa, Y., Maekawa, A., \& Takahashi, M. (1990). Toxicity and carcinogenicity of potassium bromate - a new renal carcinogen. Environmental Health Perspective, 87: 309 - 335.

32. Kulkarni, Y.A., Veeranjaneyulu, A. (2012). Toxicological Evaluation of the Methanol Extract of Gmelina arborea Roxb.Bark in Mice and Rats. Toxicol. Int. 19:2.

33. Adeneye, A.A., Ajagbonna, O.P., Adeleke, T.I., \& Bello, S.O. (2006). Preliminary toxicity and phytochemical studies of the stem bark aqueous extract of Musanga cecropioides in rats. J Ethnopharmacol. 105:374-379. 
34. Nadro, M.S, Modibbo, A.A. (2014). Effects of Pterocarpus Erinaceus Stem Bark Aqueous Extract on Anemic Rats. Scientific Research Journal (SCIRJ), 2(5), 1-4

35. CODEX Alimentarius Commission. (2018). Joint FAO/WHO Food Standards Programme. Forty-first Session Rome, Italy, 2 - 6 July 2018. Report of the 50th session of the CODEX Committee on Food Additives, Xiamen, China. 26 - 30 March 2018.
36. FAO/ WHO. (1964). Specification for the identity and putity of food additive and other toxicological evaluation: emulsifier, stabilizer, bleaching and maturating agent (seventh report of the Joint Expert Committee on food additives) FAO Nutrition Meeting Report Series, No.35; WHO Technical Report Series, No.281. 